\title{
TOPOGRAPHIC RELIEF AND SEDIMENT THICKNESS: THEIR EFFECTS ON THE THERMAL EVOLUTION OF THE OCEANIC CRUST
}

\author{
Dallas H. Abbott \\ Lamont-Doherty Geolodgical Observatory, Palisades, NY 10964 \\ Carol A. Stein \\ Dept. of Geological Sciences, Univ. of Illinois at Chicago, Chicago, IL 60680 \\ Orest Diachok
}

Naval Research Lab., Washington, D.C. 20375

\begin{abstract}
We compiled a suite of 490 heat flow measurements from the Pacific Ocean in areas with less than $85 \mathrm{~m}$ of sediment. Heat flow patterns at different basement ages vary with topographic relief. Areas with reliefs $<300$ meters are conductively blanketed at 40-60 m.y. and may stop convecting at 70-90 m.y. Areas with reliefs $>300$ meters are conductively blanketed at 70-90 m.y. and convect out to $\geq 90-110 \mathrm{~m}$.y.
\end{abstract}

\section{Introduction}

Models for the thermal evolution of the oceanic lithosphere [Parsons and Sclater, 1977; Stein and Stein, 1992] predict how heat flow and bathymetry should vary with age. However, the primary failure of such models is that the observed heat flow for oceanic crust between 0 to $70 \mathrm{Ma}$ is much less than predicted. The models assume that the crust cools solely by conduction, but instead convective heat transport within the upper crust [e.g. Lister, 1972; Williams et al., 1974; Anderson and Hobart, 1976; Sclater et al.,1976] causes low heat flow. This heat flow deficit is expressed by the heat flow ratio: the ratio of observed heat flow over the predicted heat flow. The heat flow ratio gradually increases from 0.4 near ridge crests to about 1.0 on older sea floor. The increasing heat flow ratio as the crust ages is caused by two related processes: slowing hydrothermal circulation and increasing conductive heat loss as hydraulic resistance goes up. Hydraulic resistance increases through filling of cracks and pores by alteration products [Anderson and Zoback, 1982; Wilkens et al., 1991], and the accumulation of low permeability sediment cover.

The heat flow ratio is highly variable at different sites of the same age. This variability may be controlled by two factors: sediment thickness and topography [Sclater et al., 1976]. Mean heat flow ratio values of well-sedimented young lithosphere are much higher than on poorly sedimented young lithosphere [Davis and Lister, 1977; Anderson and Hobart, 1976]. Higher topographic relief produces a larger density contrast between upwelling warm water in basement highs and cold bottom water in basement lows, suggesting that relief may also control hydrothermal circulation patterns [Hartline and Lister, 1981; Stefansson, 1983]. Because the effects of topographic relief are less well studied, we examine the effects of topographic relief upon hydrothermal circulation.

\section{Heat Flow Data Set}

For this study, we use 490 measurements from sites in the Pacific Ocean (Figure 1). We chose sites to control for two

Copyright 1992 by the American Geophysical Union.

Paper number 92GL01996

0094-8534/92/92GL-01996\$03.00 variables: sediment thickness and mean spreading rate. All heat flow sites have $<0.11$ seconds ( 85 meters) of sediment cover, either measured directly or inferred from isopach maps. Because the equatorial region has thick sediment cover, we use few heat flow values from the Galapagos spreading center and the dominant sediment type is nearly impermeable red clay. To control for spreading rate, we used isochrons to choose sites where crust formed at intermediate to fast spreading rates, i.e. $30 \mathrm{~mm} / \mathrm{yr}$ to $90 \mathrm{~mm} / \mathrm{yr}$.

All heat flow measurements have a data quality $\geq 6$. A rating of 6 indicates $\geq 2$ thermistors in the bottom if thermal conductivity is measured at the site and $\geq 3$ thermistors in the bottom if thermal conductivity is inferred from nearby sites. Heat flow measurements $<100 \mathrm{~km}$ from known hotspot tracks are not used. We do not have enough data to infer the heat flow patterns on oceanic crust $>110 \mathrm{~m}$.y old.

Because the dimensions of off-ridge hydrothermal cells are determined by topographic wavelength [Fisher et al., 1990], typically $8-30 \mathrm{~km}$ [Goff, 1991], we assessed the topographic relief within a $25 \mathrm{~km}$ radius of each station. The topographic relief is the maximum water depth minus the minimum water depth. The topographic relief defined in this way is also the majority of the hydraulic head available to drive passive hydrothermal convection [Steffansson, 1983]. Because sediment cover is thin, topographic relief is similar to basement relief.

The quality of the topographic relief estimates is based on a visual examination of the ship tracks near a heat flow site. If no tracks directly cross the site, the heat flow station is not in our final data set. If 1 to 2 tracks cross the site at angles of $<$ 45 degrees, the relief quality is 3 . If 2 to 4 tracks cross the site at angles $>45$ degrees, the relief quality is 2 . The highest quality of relief estimates uses 4 or more tracks that are well distributed around the site. The overall quality distribution is: quality $3: 185$ stations, quality $2: 118$ stations, quality $1: 187$ stations. We examined the spatial distribution of relief estimates and qualities and found no spatial bias (Figure 1).

Based on total topographic relief, the heat flow stations fall into three groups. Low relief sites have a total relief $<300 \mathrm{~m}$ and an overall mean relief of $237 \pm 52 \mathrm{~m}$. The mean relief of stations with a data quality of 1 or 2 is $242 \pm 68 \mathrm{~m}$, implying that the regional relief is not significantly underestimated at quality 3 stations (mean relief $233 \pm 44 \mathrm{~m}$ ). Moderate relief sites have total relief of $300-600 \mathrm{~m}$ and a mean relief of $432 \pm 76 \mathrm{~m}$. High relief sites have total relief $>600 \mathrm{~m}$ and a mean relief of $976 \pm 471 \mathrm{~m}$. The total sites in each category are low relief: 94, moderate relief: 204, and high relief:192.

\section{Heat Flow Patterns, Topographic Relief and Convection}

The distribution of mean heat flow ratios varies with basement relief and age but the individual ratios show great variability. Relative changes in the amount of heat flow scatter can originate from sampling bias, changes in convective 


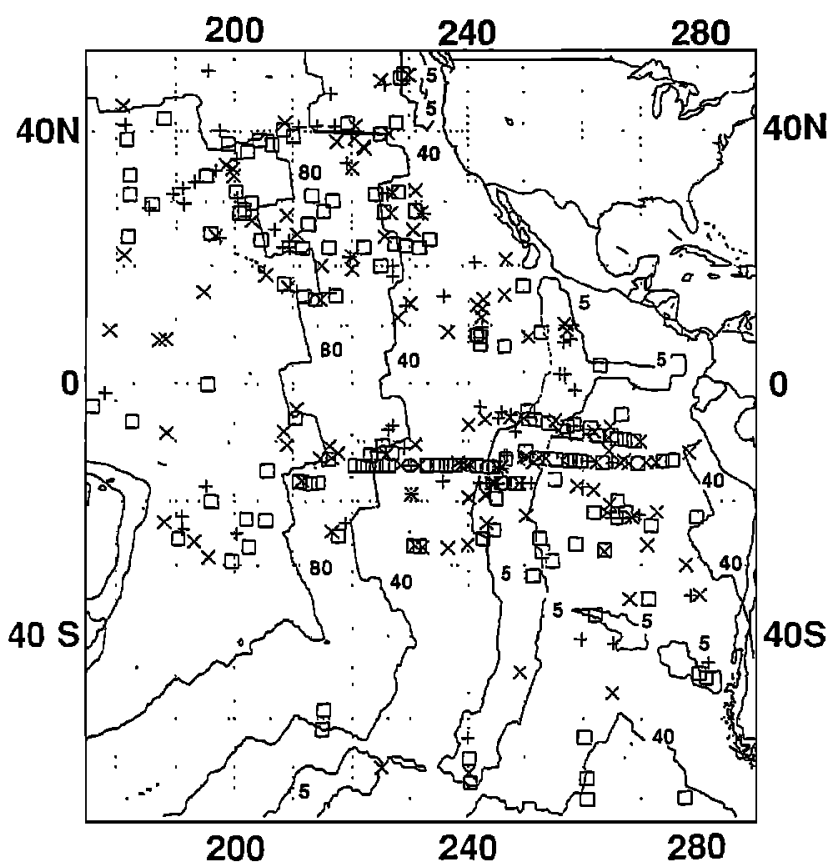

Fig. 1. Heat flow sites. Contours: 5,40 and $80 \mathrm{~m} . y$. old isochrons. Relief $+:<300 \mathrm{~m}, \mathrm{X}: 300-600 \mathrm{~m}$, squares $>600 \mathrm{~m}$.

intensity, changes in convection cell size, and changes in the basal heat flow. However, the combination of the heat flow scatter and the mean heat flow ratio is more useful (Figure 2). At crustal ages $>20 \mathrm{~m} . \mathrm{y}$, there is less scatter at sites with reliefs of 300-600 m than at sites with reliefs $>600 \mathrm{~m}$. Because the mean heat flow ratios are similar at similar crustal ages, the higher scatter at reliefs $>600 \mathrm{~m}$ may indicate a larger cell size than at reliefs of $300-600 \mathrm{~m}$. On the youngest crust, low heat flow scatter occurs with a low mean heat flow ratio, suggesting rapid convection that cools down the crust at all but a few isolated, poorly sedimented highs. On intermediate age crust, the heat flow scatter initially increases as the mean heat flow ratio increases, suggesting that slower convection and warmer basement produce more high heat flow measurements. On the oldest crust, the relative abundance of low heat flow ratios decreases and the mean heat flow ratio goes to 1.0 , suggesting either slower convection or no convection.

The means and standard deviations for the heat flow ratio in overlapping, 10-20 m.y. wide age bins are on Figure 3 (top). The age at which the Pacific lithosphere attains a heat flow ratio of 1.0 varies with relief. In low relief areas $(<300$ $\mathrm{m}$ ), the mean ratio reaches 1.0 at $\sim 40-60$ m.y. For sites with intermediate and high bathymetric relief, the mean ratios reach 1.0 at $\sim 90-100$ m.y. Anderson and Skilbeck [1981] noted that the standard error of heat flow means decreased with increasing age. Thus, for similar amounts of data $(\mathrm{N})$, regions with more convective heat transfer should also have a larger standard error in heat flow when compared to regions with only conductive heat transfer. Two caveats to this approach are that because heat flow measurements require adequate sediment cover, heat flow measurements from thinly sedimented areas may be spatially aliased towards low values, and that because off-ridge cell size depends upon topography, the mean heat flow from larger cells will have a higher standard error.

\section{Age of Conductive Blanketing and Basement Relief}

The physical conditions and mechanisms of heat transfer for regions with an average heat flow ratio of 1.0 are contro versial. In hydrothermal systems with a mean heat flow ratio $\geq 1.0_{2}$ most or all of the crust is covered by sediment. However, at some sites layer $2 \mathrm{~A}$ has relatively high permeability and basement water circulation continues [Anderson et al., 1979; Geller et al., 1983; Embley et al., 1983] despite vertical water flow through the sediment at speeds less than heat conduction rates [Fisher et al., 1990]. Thus, to first order the pore water inside layer $2 \mathrm{~A}$ is hydraulically isolated from the overlying bottom water by a conductive layer. Hence we call areas with a mean heat flow ratio of 1.0 "conductively blanketed" hydrothermal systems rather than the previously used term "seal" which could be misinterpreted to imply that all cracks and pores within layer $2 \mathrm{~A}$ are filled.

"Conductively blanketed" hydrothermal systems show heat flow patterns which depend upon whether conduction or convection dominates heat transfer. In hilly regions with only conductive heat transfer, heat flow variability results from conductive refraction through the basalt layer, which has a thermal conductivity value about twice that of deep-sea sediments. In models of ideal 2-dimensional or 3-dimensional sinusoidal topography [M. Langseth, oral comm.] with uniform sediment cover, individual heat flow ratios are evenly distributed about the mean in a pattern shaped like a Gaussian curve or a square wave. For example, conductive refraction [Davis et al., 1984] produces a roughly symmetrical heat flow pattern with 10 values below and 13 values above the mean (Figure 4). In contrast, a conductively blanketed, convecting system [Embley et al., 1983] has a skewed distribution with 38 values below and 13 values above the mean (Figure 4).

Because some regions with mean heat flow ratios $\geq 1.0$ have convection and others have only conduction we define a new parameter $\mathrm{X}^{*}$. For each bin, we calculated heat flow ratios for the individual measurements and the mean heat flow ratio for the entire bin. If the mean heat flow ratio of a bin is $\leq$ 1.0 , then $\mathrm{X}^{*}$ is the \% of heat flow ratios $<1.0$. If the mean heat flow ratio of a bin is $>1.0$, then $X^{*}$ is the $\%$ of single heat flow ratios less than the mean heat flow ratio for the bin. Because the theoretical models of Langseth and the data of
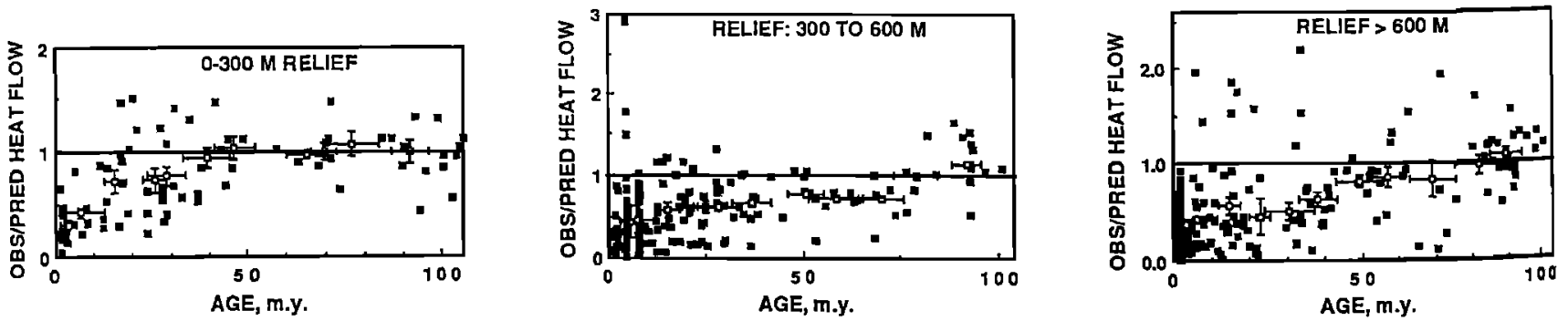

Fig. 2. Heat flow ratio v.s. basement age in m.y. Black squares: individual measurements. Open squares with error bars: mean heat flow ratio in an age bin. Age bins are spaced every $5 \mathrm{~m} . \mathrm{y}$. and 10 m.y. wide from 0-20 m.y. and spaced every $10 \mathrm{~m}$.y. and $20 \mathrm{~m}$.y. wide for $>20 \mathrm{~m}$.y. Heat flow error bars: standard error of the heat flow mean. Heat flow is grouped by relief. 

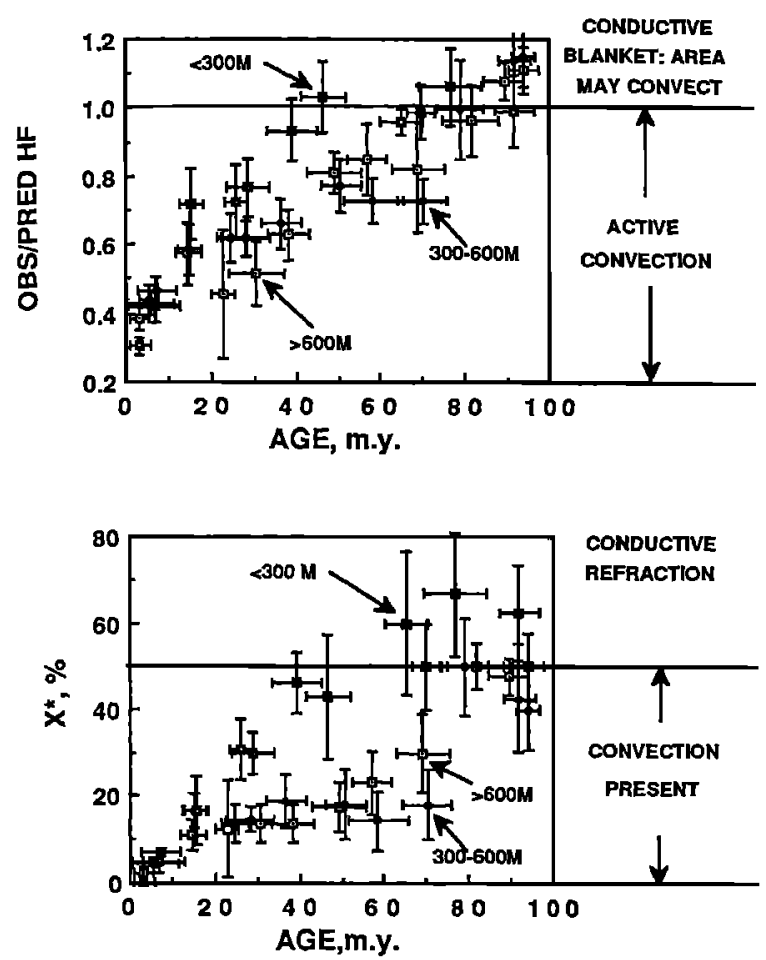

Fig. 3. Age bins same as in Figure 2. (Top). Heat flow ratio vs.age. (Bottom) $\mathrm{X}^{*}$ vs. age. Relief: $<300 \mathrm{~m}$ : closed squares, $300-600 \mathrm{~m}$ : dots, $>600 \mathrm{~m}$ : open squares.

Davis et al. [1984] indicate that systems with conduction only have an $\mathrm{X}^{*}$ value of 50 to $56 \%$; we assume that for a given bin with $\mathrm{X}^{*}>50 \%$, conductive refraction dominates heat transfer. For $\mathrm{X}^{*}<50 \%$ we assume that convection is present. Of course, the exact value of $\mathrm{X}^{*}$ dividing convection from conductive refraction depends upon our assumptions about the spatial distribution of measurements and the geometry of the basement and sediment cover. The $\mathrm{X}^{*}$ values for the three relief categories appear in Figure 3. For example, although the heat flow ratios for the 90-100 Ma bin exceed 1.0 in all three relief categories, the $X^{*}$ test suggests that convection is still present at sites with relief $>300 \mathrm{~m}$, but is not a factor at sites with relief $<300 \mathrm{~m}$.

At sites with relief $<300 \mathrm{~m}$, the system is conductively blanketed at $-40-60 \mathrm{Ma}$ (Figure 3 ) and for older ages $\mathrm{X}^{*}$ is significantly greater than $50 \%$, hence conductive refraction dominates. Although the mean heat flow ratio is $\geq 1.0$ at ages above $\sim 70 \mathrm{Ma}$, all sites with relief $>300 \mathrm{~m}$ have an $\mathrm{X}^{*}$ of $40-50 \%$, suggesting that convection is present and conductive refraction is only starting to dominate heat transfer (Figure 3).
The age at which the Pacific oceanic crust attains a heat flow ratio of 1.0 varies with basement relief. The sites with reliefs below 300 meters are conductively blanketed at $40-60 \mathrm{~m}$.y old (Figure 4). The crossover between heat flow patterns ruled by conductive refraction and heat flow patterns ruled by convection occurs at $\sim 70-90 \mathrm{~m}$.y. The higher relief sites, with relief $>300 \mathrm{~m}$, are conductively blanketed at 70-90 m.y (Figure 3). The higher relief sites show the convective type pattern of heat flow ratios out to the oldest age bin in this study, 90-110 m.y.

\section{Discussion}

Given our results, we reconsider why "reliable" heat flow sites with $\geq 150-200 \mathrm{~m}$ of sediment cover within $18 \mathrm{~km}$ of the site [Sclater et al., 1976] averaged higher heat flow than less "reliable" sites. Our work suggests that both the sediment thickness distribution and the maximum topographic relief are important Thus, away from areas with "active circulation" [Lister, 1982] , the relief and sediment thickness distribution may control the convection.

We suggest two alternative explanations for our observations that oceanic crust with low relief has on average higher heat flow ratios than at sites with $>300 \mathrm{~m}$ of relief and that the mean heat flow ratios of moderate and high relief sites are not significantly different. The first is that the oceanic crust must be totally covered by low permeability sediment to produce the necessary hydraulic resistance to stop convection [Jacobson, 1992]. Crust with low relief is easier to blanket with sediment because there are fewer (or no) fault scarps with slopes above the angle of repose of the sediment. If low permeability, relatively continuous sediment cover impedes and eventually stops convection, then there may be little difference between the convective behavior of moderate and high relief crust, both of which have many steep fault scarps. A second, although not mutually exclusive idea is that convection ceases when circulation slows enough for pore water concentrations to reach a certain critical threshold for precipitation of crack fills, primarily calcite. This hypothesis is consistent with the finding of Gallahan and Duncan [1991] that the celadonite ages of neighboring fracture fills in the Troodos ophiolite were youngest in areas of high inferred paleo-permeability and oldest in areas of low inferred paleo-permeability. Their data suggest that the velocity of porous flow is a critical control on crack fill precipitation. If convective velocity is important, then with other factors being equal; the greater hydraulic head of high relief crust should drive convection longer than in moderate relief crust.

Testing these two hypotheses will involve further examination of comelations of the heat flow ratio with several factors: 1) the uniformity of sediment cover as a function of topographic relief, 2) the convection rate of hydrothermal cells with differing topographic relief, and 3) the areal distribution of hydraulic head as a function of overall topographic relief.

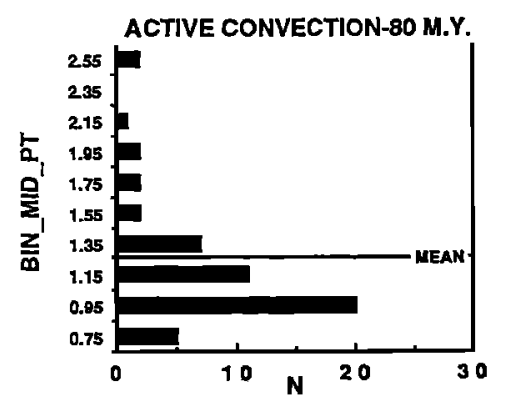

Fig. 4. Heat flow ratio histograms (Right): No convection. $\mathrm{X}^{*}$ is $56.5 \%$. (Left): Convecting, conductively blanketed

\section{NO CONVECTION: 155 M.Y.-1.5 KM SED.}

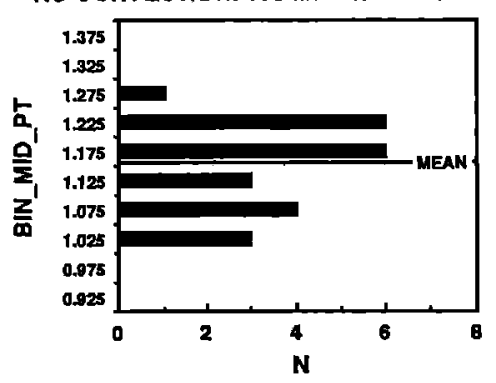

system. $X^{*}$ is $25.5 \%$. Heat flow is averaged in $1^{\prime}$ bins to remove areal sampling bias. 


\section{Conclusions}

The heat flow ratio generally increases with increasing basement age. Topographic relief is an important control on the heat flow ratio at a given age. In poorly sedimented regions, the heat flow ratio is significantly higher for sites with low relief $(<300 \mathrm{~m})$ compared to sites with intermediate $(300$ $600 \mathrm{~m})$ or high $(>600 \mathrm{~m})$ relief. When the heat flow ratio reaches 1.0, at $\sim 40-60$ m.y. crust for the lowest relief sites, and $70-90 \mathrm{~m}$.y. crust for $>300 \mathrm{~m}$ relief sites, then we call the crust "conductively blanketed". At mean heat flow ratios $\geq 1.0$, significantly more single heat flow ratios less than the mean ratio may indicate active convection. Using this criteria, the average area with relief $<300 \mathrm{~m}$ has no convection after $60 \mathrm{Ma}$, but convection continues in areas with greater relief even after the heat flow ratio is $\geq 1.0$.

Acknowledgements. We thank W. Menke, M. Langseth, N. Sleep and J. Weissel for criticism. This work was supported by contracts N00173-91-M-6479 and N00014-92-J-1187. Lamont-Doherty Geological Observatory contribution \# 4983.

\section{References}

Abbott, D.H., W. Menke, and R. Morin, Constraints upon water advection in sediments of the Mariana Trough, $I$. Geophys. Res. 88, 1075-1093, 1983.

Anderson, R.N., and M.A. Hobart, The relation between heat flow, sediment thickness, and age in the eastern Pacific, $J$. Geophys. Res., 81, 2968-2989, 1976.

Anderson, R.N., and J.G. Skilbeck, Oceanic heat flow, in The Sea, 7, The Oceanic Lithosphere, edited by C. Emiliani, pp. 489-523, John Wiley, New York, 1981.

Anderson, R.N., and M.D. Zoback, Permeability, underpressure, and convection in the oceanic crust near the Costa Rica rift, eastern equatorial Pacific, I. Geophys, Res. 17 , 3447-3457, 1982.

Anderson, R.N., M.G. Langseth, and J.G. Sclater, The mechanisms of heat transfer through the floor of the Indian Ocean, J. Geophys. Res., 82, 3391-3408, 1977.

Anderson, R.N., M.A. Hobart, and M.G. Langseth, Geothermal convection through oceanic crust and sediments in the Indian Ocean, Science, 204, 828-832, 1979.

Davis. E.E., and C.R. B. Lister, Heat flow measured over the Juan de Fuca Ridge: evidence for widespread hydrothermal circulation in a highly heat transportive crust, I. Geophys, Res, 82, 4845-4860, 1977

Davis, E.E., C.R.B. Lister, and J.G. Sclater, Towards determining the thermal state of old ocean lithosphere: heatflow measurements from the Blake-Bahama outer ridge, north-western Atlantic, Geophys. J. R astron. Soc, 78. 507-545, 1984.

Embley, R.N., M.A. Hobart, R.N. Anderson, and D.Abbott, Anomalous heat flow in the northwest Atlantic: A case for continued hydrothermal circulation in $80 \mathrm{~m}$.y. old crust, $\mathrm{J}$ Geophys. Res. 88, 1067-1074, 1983.

Fisher, A.T., K. Becker, T.N. Narisimhan, M.G. Langseth, and M.J. Mottl, Passive, off-axis convection through the southern flank of the Costa Rica Rifh, J. Geophys. Res., 25, 9343-9370, 1990.

Gallahan, W.E., and R.A. Duncan, K-Ar ages of celadonites from the Troodos ophiolite, Cyprus: A new estimate for the duration of hydrothermal alteration in oceanic crust, EOS. 72. 453, 1991.

Geller, C.A., J. K. Weissel, and R.N. Anderson, Heat transfer and intraplate deformation in the central Indian Ocean, I. Geophys. Res., 88, 1018-1032, 1983.

Goff, J.A., A global and regional stochastic analysis of nearridge abyssal hill morphology, I. Geophys. Res., 96. 21,713-21,737, 1991.

Hartline, B.K., and C. R. B. Lister, Topographic forcing of supercritical convection in a porous medium such as the oceanic crust, Earth Planet Sci. Lett, 55, 75-86, 1981.

Herman, B.M., M.G. Langseth, and M.A. Hobart, Heat flow in the oceanic crust bounding West Africa, Tectonophysics, 41, 61-78, 1977.

Jacobson, R.S., Impact of crustal evolution on changes of the seismic properties of the uppermost ocean crust, Rev. Geophys. 30, 23-42, 1992.

Langseth, M.G., K. Becker, R.P.Von Herzen, and P. Schultheiss, Heat and fluid flux through sediment on the western flank of the mid-Atlantic Ridge: a hydrogeological study of North Pond, Geophys. Res. Lett., 19. 517-520, 1992.

Lister, C.R.B., On the thermal balance of a mid-ocean ridge, Geophys. J. R. Astron, Soc, 26, 515-535, 1972.

Lister, C.R.B., "Active" and "Passive" hydrothermal systems in the oceanic crust: predicted physical conditions, in The Dynamic Evolution of the Ocean Floor, edited by K.A. Fanning and F.T. Mannheim, pp. 441-470, 1982.

Parsons, B., and J. G. Sclater, An analysis of the variation of ocean floor bathymetry and heat flow with age, $J$. Geophys. Res. 82, 803-827, 1977.

Sclater, J.G., J. Crowe, and R.N. Anderson, On the reliability of oceanic heat flow averages, J.Geophys. Res., 81, 2997-3006, 1976

Stefansson, V., Physical environment of hydrothermal systems in Iceland and on submerged oceanic ridges, pp. 321-360, in Hydrothermal Processes at Seafloor Spreading Centers. edited by P. A. Rona et al., Plenum, New York, 796 pp., 1983.

Stein, C. A., and S. Stein, A model for the global variation in oceanic depth and heat flow with lithospheric age, Nature, accepted, 1992.

Wilkens, R.H., G.J. Fryer, and J. Karsten, Evolution of porosity and seismic structure of upper oceanic crust: Importance of aspect ratios, L. Geophys. Res., 26, 1798117995, 1991.

Williams, D.L., R.P. Von Herzen, J.G. Sclater and R.N. Anderson, The Galapagos spreading center: lithospheric cooling and hydrothermal circulation, Geophys. J. R. astr. Soc., 38, 587-608, 1974

Dallas Abbott, L.D.G.O, Palisades, NY 10964

Carol Stein, Geol. Dept., U.I.C., Chicago, IL 60680

Orest Diachok, Naval Res. Lab, Washington, D.C. 20375

(Received: June 16, 1992

Revised: August 13, 1992

Accepted: August 19, 1992) 